\title{
An updated checklist of Chironomidae (Diptera) from the Amur River basin (Russian Far East)
}

\author{
Nadezhda M. YAVORSKAYA,, $2^{1 *}$ Marina A. MAKARCHENKO,${ }^{3}$ Oksana V. OREL, ${ }^{3}$ Eugenyi A. MAKARCHENKO ${ }^{3}$ \\ ${ }^{1}$ Institute for Water and Ecological Problems Far Eastern Branch, Russian Academy of Sciences, 680000 Khabarovsk; ${ }^{2}$ Joint Directorate \\ of State Natural Reserves and National Parks of Khabarovsk Territory «Zapovednoye Priamurye», Khabarovsk 680000; ${ }^{3}$ Federal \\ Scientific Center of the East Asia Terrestrial Biodiversity, Far East Branch of the Russian Academy of Sciences, 100 let Vladivostoku \\ 159, 690022 Vladivostok, Russia \\ *Corresponding author: yavorskaya-tinro@mail.ru
}

\begin{abstract}
A long-term study implemented in the Amur River basin enabled us to generate an updated checklist of 606 valid species in Chironomidae (Diptera) which are composed of 129 genera and six subfamilies, with 98 (17\%) described new species belonging to 46 genera. Among the 98 recently described species, 46 ones (45\%), were considered as possible endemics and sub-endemics. The numbers of species and genera by subfamilies is as follows: Podonominae ( 3 species; 3 genera), Tanypodinae (17; 9), Diamesinae $(25 ; 11)$, Prodiamesinae $(7 ; 3)$, Orthocladiinae $(307 ; 57)$ and Chironominae $(247 ; 46)$. The higher numbers of species (421 and 410, respectively) were recorded in the Lower and Middle parts of the Amur River basin, as compared with the Upper part of the basin. Most of the recorded chironomids (387 species, 67\%) are Palaearctic in distribution, while others (191, 33\%) are widely Holarctic. Species with Palaearctic distribution mostly have the following range types: East Palaearctic continental (23\%); East Palaearctic continental-insular (20\%); Palaearctic transpalaearctic (14\%); Palaearctic amphi-Eurasian (10\%).
\end{abstract}

Key words: Diptera; Chironomidae; geographical distribution; subendemics; Amur River basin; Russian Far East.

Received: February 2018. Accepted: July 2018.

This paper was presented at the $20^{\text {th }}$ International Symposium on Chironomidae, Trento, Italy, 2-8 July 2017. Session: Ecology and Biomonitoring.

\section{INTRODUCTION}

The Amur River is one of the longest (4416 km long) and the greatest rivers in East Asia. It is located in East Siberia, the Far East of Russia (Transbaikalia, Amur Region, Jewish Autonomous Region, Khabarovsk and Primorye Territories), NE Mongolia and NE China. The river is customary divided into three parts: the upper, middle and lower Amur. The Upper Amur begins at the juncture of the Shilka and Argun and ends at the mouth of the Zeya River near of Blagoveshchensk City. The Middle Amur extends from the Zeya River to Khabarovsk City. And the Lower Amur is part of river from Khabarovsk to the mouth (Fig. 1). Its basin includes 10,610 streams and 61,427 lakes.

The first studies of the chironomids of the Amur River basin are referred to the work of Soldatov (1915). He collected plankton and benthos in 1907-1913 and found that chironomid larvae were one of the main components of fish feeding and benthic communities, but information on the taxonomic composition was not given. The first work on the chironomid taxonomy was the paper by Goetghebuer (1933). Basing on materials collected by
A.A. Stackelberg and S.I. Obolensky in the basin of the Khanka Lake, he recorded 16 species of subfamilies Tanypodinae, Orthocladiinae and Chironominae by adults and 6 species of them were new to science. During the hydrobiological study of the material collected in the Lower Amur by the Pacific Research Institute of Fisheries and Oceanography (TINRO), 24 genera of chironomids were identified by larvae (Mikulich, 1948). In 1945-1949, during the "Complex Amur Ichthyologic Expedition" huge hydrobiological studies in the Amur River basin were carried out. The material was collected from about 50 different water bodies in the Middle and Lower Amur and surrounding areas. As a preliminary result of this expedition, 127 species and 'larval forms' of chironomids belonging to 5 subfamilies were identified in benthic and entomological samples, which included material of both larvae and adults (Konstantinov, 1950, 1952a, 1952b; Shilova, 1954), and were described 8 new species. Further study on the food chains in fish populations conducted by the Amur branch of TINRO from 1948 to 1982 in the Amur River basin, as well as our investigations of 20042008 made it possible to compile and update a list of 275 chironomid, species. This list, first published by 
Makarchenko et al. (2005), was then upgraded to 404 species by Makarchenko and Makarchenko (2008a) and Makarchenko et al. (2008). During the last decade, the new data were obtained on the fauna, taxonomy and distribution of chironomids in the Amur River basin and were described a news species by us, based on both traditional morphological and molecular genetic methods (Makarchenko and Makarchenko, 2007, 2008a, 2008b, 2008c, 2009a, 2009b, 2010a, 2010b, 2010c, 2010d, 2012a, 2012b, 2012c, 2014, 2015a, 2015b; Makarchenko and Semenchenko, 2014; Makarchenko et al., 2005, 2014, 2015, 2017a, 2017b).

In the present paper, an updated and annotated checklist of chironomids for the Upper, Middle and Lower Amur basins is provided based on the original and recently published data, with a discussion of the taxonomic diversity and types of ranges of valid species.

\section{METHODS}

The material summarized in this paper was collected between 2009 and 2017 from various standing and running waters in the Middle and Lower Amur River basins, mostly by the authors and Drs T.M. Tiunova and V.A. Teslenko (the Laboratory of Freshwater Hydrobiology, Federal Scientific Center of the East Asia Terrestrial Biodiversity, Far East Branch of the Russian Academy of Sciences). The material of adults was collected during swarming of chironomids or from riparian vegetation, mostly using hand netting and netsweeping and, in addition, using light traps and Malaise traps. The pupae and larvae were taken from hydrobiological samples of zoobenthos, or collected with standard drift nets. Adults of some species were reared from larvae in the field. In addition, DNA barcoding (COI

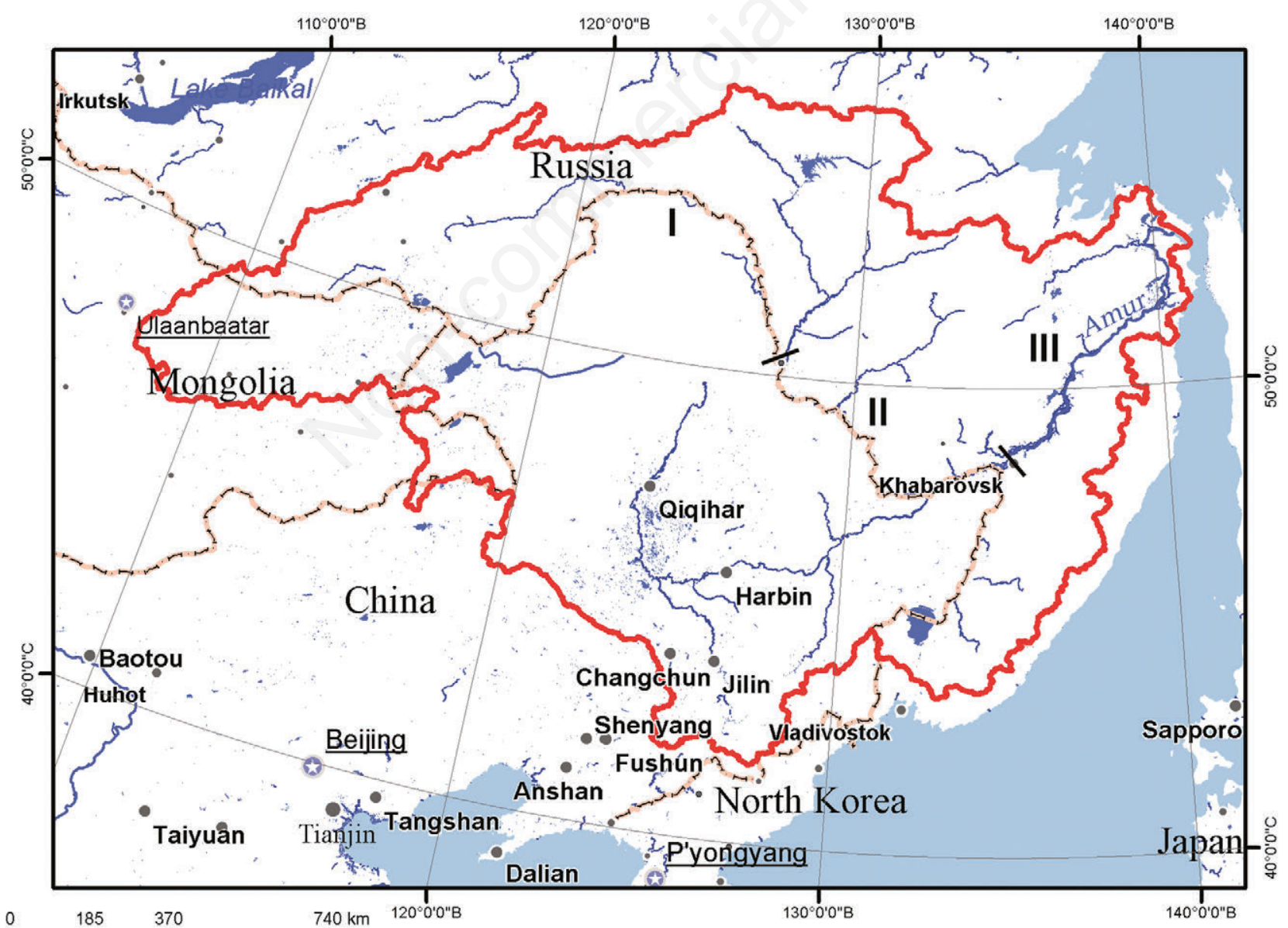

Fig. 1. The three major physiographic regions of the Amur River basin. I, Upper Amur; II, Middle Amur; III, Lower Amur. 
sequences) was used to clarify the species identifications (Makarchenko and Semenchenko, 2014; Makarchenko et al., 2015, 2017a, 2017b). The techniques of preservation of material, slide-mounting and identification were used as described by Makarchenko (2006). Geographical range types are considered according to Gorodkov (1984).

\section{RESULTS AND DISCUSSION}

An updated checklist includes 606 valid chironomid species in 129 genera recorded from the Amur River basin (Tab. S1). This list is tabulated in six subfamilies: Podonominae ( 3 species in 3 genera), Tanypodinae (17 species in 9 genera), Diamesinae ( 25 species in 11 genera), Prodiamesinae ( 7 species in 3 genera), Orthocladiinae (307 species in 57 genera) and Chironominae ( 247 species in 46 genera). The numbers of species recorded from the Lower and Middle Amur River basins (421 and 410, respectively) were higher than that in the Upper Amur basin (only 66 spp.) (Tab. 1). The knowledge of chironomids in the Upper Amur basin is lower, it includes poorly explored areas and wetlands, which are difficult to access.

A taxonomic analysis of all new species found since 1933 to 2017 showed that some species described by Goetghebuer (1933) and Shilova (1952) in imago were synonymized, and the species described by Konstantinov $(1952 b)$ in the larvae were placed to the nomena dubia. Considering these data, the total number of new species for the Amur River basin currently is 98 of 46 genera (Tab. 2). About $50 \%$ of the listed species were previously known only from Japan; they are recorded for the first time from Russia. In the near future, we plan to describe at least 11 new species belonging to the genera Georthocladius Strenzke, Hydrobaenus Fries, Polypedilum Kieffer, Robackia Sæther, Stictochironomus Kieffer, Cladotanytarsus Kieffer, Micropsectra Kieffer, Neozavrelia Goetghebuer, Paratanytarsus Thienemann et Bause, Rheotanytarsus Thienemann et Bause and Tanytarsus v. d.
Wulp. Additional DNA barcoding will be provided for some of the new undescribed species belonging to the genera Micropsectra, Cladotanytarsus and Neozavrelia. Of the 98 described new species, 43 mostly belonging to the Orthocladiinae are possible endemics or subendemics; they are considered as exclusive and biogeographic representative of the Amur River basin (Tab. S1), e.g. Abiskomyia korbokhon, Propsilocerus amurensis, Paralimnophyes dolgikh, Hydrobaenus golovinensis, Tokunagaia logutini, Chaetocladius antipovae, C. egorych, C. fedotkin, C. yavorskayae, Parasmittia bidzhanica, Tsudayusurika safonikha and Tvetenia bidzhanica. Abiskomyia korbokhon occurs only in oligotrophic Korbokhon Lake, which is situated at an altitude of 1160 $\mathrm{m}$ above sea level in the upper reach of the Bureya River (Middle Amur) (Makarchenko and Makarchenko, 2015b); P. amurensis is also known only from its type locality, the Kadi River near the Bolon Nature Reserve (Lower Amur) (Makarchenko and Makarchenko, 2009b); P. dolgikh, H. golovinensis and T. logutini are reported from running waters of the Bolshekhekhtsirsky Nature Reserve (Lower Amur) (Makarchenko et al., 2015, 2017b; Yavorskaya et al., 2017). The other above-listed species occur only at the springs of the Bidzhan River basin (Middle Amur) (Makarchenko et al., 2014, 2017a). Three species of the subfamily Chironominae are known only from the single site: Dicrotendipes ovaleformis from the Ussuri River; $D$. unicus from the Kiya River (Lower Amur); Paracladopelma urkanensis from the Zeya River (Middle Amur) (Zorina, 2001, 2006).

Most of the recorded chironomids (387 species or $67 \%$ ) are widely distributed in the Palaearctic Region, while others (191 species or 33\%) are Holarctic in distribution. The listed Palaearctic species mostly represent the following range types: East Palaearctic continental (23\% of species); East Palaearctic continentalinsular (20\%); Palaearctic transpalaearctic (14\%); Palaearctic amphi-Eurasian (10\%). Other types of geographical distribution are rare.

Tab. 1. The numbers of chironomid species in different subfamilies, known from the Upper, Middle and Lower basins of the Amur River.

\begin{tabular}{|c|c|c|c|c|c|c|}
\hline \multirow[t]{2}{*}{ Subfamilies } & \multicolumn{2}{|c|}{ Upper Amur River } & \multicolumn{2}{|c|}{ Middle Amur River } & \multicolumn{2}{|c|}{ Lower Amur River } \\
\hline & Species & Genera & Species & Genera & Species & Genera \\
\hline Podonominae & 1 & 1 & 3 & 3 & 2 & 2 \\
\hline Tanypodinae & 4 & 3 & 10 & 6 & 16 & 8 \\
\hline Diamesinae & 6 & 5 & 16 & 9 & 17 & 8 \\
\hline Prodiamesinae & 1 & 1 & 4 & 2 & 6 & 3 \\
\hline Orthocladiinae & 19 & 13 & 185 & 55 & 225 & 52 \\
\hline Chironominae & 35 & 24 & 192 & 43 & 155 & 40 \\
\hline Total & 66 & 47 & 410 & 118 & 421 & 113 \\
\hline
\end{tabular}


Tab. 2. Numbers of species described in different genera of Chironomidae from the Amur River basin.

\begin{tabular}{|c|c|c|c|}
\hline Subfamily and genus & New species & Subfamily and genus & New species \\
\hline Tanypodinae & & Parasmittia Strenzke & 1 \\
\hline Clinotanypus Kieffer & 1 & Prosmittia Brundin & 1 \\
\hline Diamesinae & & Pseudorthocladius Goetghebuer & 2 \\
\hline Arctodiamesa Makarchenko & 1 & Pseudosmittia Edwards & 2 \\
\hline Prodiamesinae & & Rheocricotopus Brundin & 1 \\
\hline Monodiamesa Kieffer & 2 & Smittia Holmgren & 1 \\
\hline Prodiamesa Kieffer & 1 & Stilocladius Rossaro & 1 \\
\hline Orthocladiinae & & Symbiocladius Kieffer & 1 \\
\hline Abiskomyia Edwards & 1 & Thienemanniella Kieffer & 1 \\
\hline Boreosmittia Tuiskunen & 2 & Tokunagaia Sæther & 4 \\
\hline Bryophaenocladius Thienemann & 4 & Tsudayusurica Sasa & 1 \\
\hline Chaetocladius Kieffer & 7 & Tvetenia Kieffer & 3 \\
\hline Corynoneura Winnertz & 3 & Vivacricotopus Schnell et Sæther & 3 \\
\hline Cricotopus van der Wulp & 6 & Chironominae & \\
\hline Eukiefferiella Thienemann & 2 & Beckidia Sæther & 2 \\
\hline Heterotrissocladius Spärck & 2 & Cryptochironomus Kieffer & 1 \\
\hline Hydrobaenus Fries & 8 & Dicrotendipes Kieffer & 3 \\
\hline Krenosmittia Thienemann et Krüger & 1 & Olecryptotendipes Zorina & 1 \\
\hline Limnophyes Eaton & 1 & Paracladopelma Harnisch & 3 \\
\hline Metriocnemus van der Wulp & 3 & Phaenopsectra Kieffer & 2 \\
\hline Nanocladius Kieffer & 1 & Polypedilum Kieffer & 4 \\
\hline Orthocladius van der Wulp & 3 & Stenochironomus Kieffer & 2 \\
\hline Parakiefferiella Thienemann & 2 & Synendotendipes Grodhaus & 1 \\
\hline Paralimnophyes Brundin & 1 & Constempellina Kieffer & 1 \\
\hline Propsilocerus Kieffer & 1 & Zavrelia Kieffer & 2 \\
\hline Parorthocladius Thienemann & 1 & & \\
\hline
\end{tabular}

\section{ACKNOWLEDGMENTS}

We are grateful to Drs T.M. Tiunova and V.A. Teslenko (Federal Scientific Center of the East Asia Terrestrial Biodiversity, Far East Branch of the Russian Academy of Sciences, Vladivostok) for making the material available to us. Special thanks are due to the administration of Joint Directorate of State Natural Reserves and National Parks of Khabarovsk Territory "Zapovednoye Priamurye" for facilities and support provided during our investigations in the nature reserves located in the Amur River basin.

\section{REFERENCES}

Goetghebuer M, 1933. [Ceratopogonidae et Chironomidae de la Sibérie Orientale].[Article in French]. Bull. Ann. de Soc. Roy. Entomol. Belg. 73:111-120.

Gorodkov KB, 1984. [Insect range types of tundra and forest zones of the European part of the USSR].[Article in Russian]. Insect ranges of the European part of the USSR. Nauka, Leningrad.

Konstantinov AS, 1950. [Chironomids of the Amur River basin and their role in feeding of Amur fishs]. [Article in Russian]. Proceed. Amur Ichtyol. Exped.1945-1949. 1:147-286.

Konstantinov AS, 1952a. [On chironomid fauna of the Ussuri River basin and Khanka Lake]. [Article in Russian]. Proceed. Amur Ichtyol. Exped.1945-1949. 3:381-389.

Konstantinov AS, 1952b. [New chironomid larvae from Amur River basin]. [Article in Russian]. Proceed. Amur Ichtyol. Exped.1945-1949. 3:390-395.

Makarchenko EA, Makarchenko MA, Zorina OV, Sergeeva IV, 2005. [Preliminary data on fauna and taxonomy of chironomids (Diptera, Chironomidae) of the Russian Far East]. [Article in Russian]. Vladimir Ya. Levanidov's Biennial Memorial Meetings. Dal'nauka, Vladivostok. 3:394-420.

Makarchenko EA, 2006. [Fam. Chironomidae - midges], p. 204235. In: Lelej, AS (Ed.), Key to the insects of the Russian Far East].[Article in Russian]. V. 6. Diptera and Siphonaptera. Pt 4. Dal'nauka, Vladivostok. 
Makarchenko EA, Makarchenko MA, 2007. Chironomids of Prosmittia Brundin (Diptera, Chironomidae, Orthocladiinae) from the Russian Far East. Russian Entomol. J. 16:119-122.

Makarchenko EA, Makarchenko MA, 2008a. [Additions and corrections to the Orthocladiinae (Diptera, Chironomidae) fauna of the Russian Far East].[Article in Russian]. Vladimir Ya. Levanidov's Biennial Memorial Meetings. Dal'nauka, Vladivostok. 4:172-186.

Makarchenko EA, Makarchenko MA, 2008b. [New findings of chironomids (Diptera, Chironomidae, Orthocladiinae) in Far East and bordering territories. III. Orthocladius van der Wulp]. [Article in Russian]. Eurasian Entomol. J. 7:243262.

Makarchenko EA, Makarchenko MA, 2008c. Review of the genus Pseudosmittia Edwards (Diptera, Chironomidae, Orthocladiinae) from the Russian Far East. Russian Entomol. J. 17:215-226.

Makarchenko EA, Makarchenko MA, Zorina OV, Yavorskaya NM, 2008. [Preliminary data on chironomid fauna (Diptera, Chironomidae) of the Amur River basin. Freshwater ecosystems of the Amur River Basin].[Article in Russian]. Dal'nauka, Vladivostok. 1: 87-208.

Makarchenko EA, Makarchenko MA, 2009a. [New findings of chironomids (Diptera, Chironomidae) in Far East and bordering territories. VII. Bryophaenocladius Thienemann]. [Article in Russian]. Euras. Entomol. J. 8(Suppl.1):51-63.

Makarchenko EA, Makarchenko MA, 2009b. Propsilocerus amurensis sp.n. (Diptera, Chironomidae, Orthocladiinae) from Amur River basin (Russian Far East). Eurasian Entomol. J. 8:261-263.

Makarchenko EA, Makarchenko MA, 2010a. [New data on chironomid fauna and taxonomy of the genus Corynoneura Winnertz (Diptera, Chironomidae, Orthocladiinae) of the Russian Far East and bordering territories].[Article in Russian]. Eurasian Entomol. J. 9(3): 353-370.

Makarchenko EA, Makarchenko MA, 2010b. Hydrobaenus tiunovi sp.n. (Diptera, Chironomidae, Orthocladiinae) from Sokhondinsky State Biosphere Reserve (Zabaikal'sky Territory, Russia). Eurasian Entomol. J. 9:411-412.

Makarchenko EA, Makarchenko MA, 2010c. [New findings of chironomids (Diptera, Chironomidae, Orthocladiinae) in Far East and bordering territories. IX. Genus Eukiefferiella Thienemann].[Article in Russian]. Eurasian Entomol. J. 9:65-82.

Makarchenko EA, Makarchenko MA, 2010c. [Review of the chironomid genus Parakiefferiella Thienemann (Diptera, Chironomidae, Orthocladiinae) of the Russian Far East]. Article in Russian]. Eurasian Entomol. J. 9:397-410.

Makarchenko EA, Makarchenko MA, 2012a. [Preimaginal stages of development of some species of Far Eastern chironomids of the subfamily Orthocladiinae (Diptera, Chironomidae)].[Article in Russian]. Eurasian Entomol. J. 11:115-128.

Makarchenko EA, Makarchenko MA, 2012b. [Revew of the genus Pseudorthocladius Goetghebuer, 1943 (Diptera, Chironomidae, Orthocladiinae) of the Russian Far East].[Article in Russian]. Eurasian Entomol. J. 11:75-82.

Makarchenko EA, Makarchenko MA, 2012c. [Review of the genus Tvetenia Kieffer (Diptera, Chironomidae, Orthocladiinae) of the Russian Far East and bordering territories].[Article in Russian]. Eurasian Entomol. J. 11(Suppl.1):137-152.

Makarchenko EA, Makarchenko MA, 2014a. [New findings of chironomids (Diptera, Chironomidae, Orthocladiinae) in Far East and bordering territories. XII. The genus Metriocnemus van der Wulp, 1874].[Article in Russian]. Eurasian Entomol. J. 13:35-40.

Makarchenko EA, Makarchenko MA, Zorina OV, 2014. [Preliminary data onchironomid fauna (Diptera, Chironomidae) of the Bidzhan River basin (Jewish Autonomous Region, Russian Far East)].[Article in Russian]. Vladimir Ya. Levanidov's Biennial Memorial Meetings. Dal'nauka, Vladivostok. 6: 21-434.

Makarchenko EA, Semenchenko AA, 2014. Morphological redescription and DNA barcoding of Linevitshia prima Makarchenko, 1987 (Diptera, Chironomidae, Diamesinae) from Amur River basin (Russian Far East), with notes on systematics of the genus. Zootaxa 3872:355-364.

Makarchenko EA, Makarchenko MA, 2015a. A review of the genus Parorthocladius Thienemann, 1935 (Diptera, Chironomidae, Orthocladiinae) from the Russian Far East. Zootaxa. 3974(3): 413-423.

Makarchenko EA, Makarchenko MA, 2015b. Review of the genus Abiskomyia Edwards (Diptera, Chironomidae, Orthocladiinae), with description of new taxa from the Russian Far East and bordering territories. Zootaxa 3919:41-60.

Makarchenko EA, Makarchenko MA, Semenchenko AA, 2015. Morphological description and DNA barcoding of Paralimnophyes dolgikh sp.n. (Diptera, Chironomidae, Orthocladiinae) from the Bolshekhehtsyrsky Nature Reserve (Khabarovsk Territory, Russian Far East). Eurasian Entomol. J. 14:392-396.

Makarchenko EA, Makarchenko MA, Semenchenko AA, 2017a. New or little-known species of Chaetocladius s. str. Kieffer, 1911 (Diptera, Chironomidae, Orthocladiinae) from the Amur River basin (Russian Far East). Zootaxa 4247:313-330.

Makarchenko EA, Makarchenko MA, Semenchenko AA, Veliaev OA, 2017b. Morphological description and DNA barcoding of Hydrobaenus golovinensis sp. nov. (Diptera, Chironomidae, Orthocladiinae) from the Russian Far East. Zootaxa 4286:277-284.

Mikulich LV, 1948. [The experience of quantitative accounting of benthos and plankton part of the Amur River bed and some floodplain reservoirs].[Article in Russian]. Izvestia TINRO. 27:139-164.

Shilova AI, 1952. [Materials on chironomid systematic of the genera Glyptotendipes and Endochironomus (Diptera)]. [Article in Russian]. Proceed. Amur Ichtyol. Exped.19451949. 3:403-418.

Soldatov VK, 1915. [A review of the studies carried out on the Amur River in 1909-1913].[Article in Russian]. Materialy k poznaniyu Russkogo rybolovstva. Petrograd. 3:1-93.

Yavorskaya NM, Makarchenko MA, Orel OV, Makarchenko EA, 2017. [The chironomid fauna (Diptera, Chironomidae) of the Bolshekhekhtsirsky Nature Reserve (Khabarovskii Krai, Russia)].[Article in Russian]. Eurasian Entomol. J. 16:180-191.

Zorina OV, 2001. [Five new species of the tribe Chironomini (Diptera, Chironomidae, Chironominae) from the Russian Far East].[Article in Russian]. Vestnik zoologii. 35:31-38.

Zorina OV, 2006. Non-biting midges of the genus Paracladopelma Harnisch (Diptera: Chironomidae) from the Russian Far East. Zootaxa 1134:29-49. 